\title{
Comparação da atividade anti-histamínica da clemastina e da pirilamina em íleo de Cavia porcelus (cobaio)*
}

\author{
LUCIANE CRISTINA VIEIRA
}

Augusto Langeloh (Orientador - UFRGS)

Banca: Eliane Maria Zanchet (UFSM), Fátima Tereza Alves Beira (UFPel), João Roberto Braga de Mello (UFRGS)

O presente trabalho teve como objetivo comparar fármacos utilizados como anti-histamínicos na terapêutica de patologias alérgicas em pequenos animais. O modelo empregado foi órgão isolado in vitro (íleo de Cavia porcelus), o qual permitiu avaliar as variáveis farmacológicas $\mathrm{DE}_{50}, \mathrm{E}_{\text {máx }}, \mathrm{pD}_{2}, \mathrm{pD}_{2}{ }_{2}$ e $\mathrm{pA}_{2}$. Comparamos as ações produzidas em curvas concentração-efeito para histamina e acetilcolina frente a diferentes concentrações de clemastina e pirilamina. Difenidramina foi empregada como controle. Os resultados permitiram confirmar que os dois fármacos atuaram efetivamente como anti-histamínicos no íleo isolado de Cavia porcelus. O principal efeito foi de antagonismo competitivo, porém, em concentrações maiores, apresentaram efeito não-competitivo e perderam a especificidade aos receptores da histamina. A clemastina com $\mathrm{pA}$, de 8,63 foi 10 vezes mais potente do que a pirilamina $\left(\mathrm{pA}_{2}=7,61\right)$ como anti-histamínico, mas também apresentou significativo $(P<0,05$; ANOVA, Bonferroni) efeito anticolinérgico, o qual não foi observado com a pirilamina. Entretanto, em concentrações mais elevadas, ambos apresentaram efeito anticolinérgico por mecanismo não-competitivo: clemastina a partir de $10^{-7} \mathrm{~mol} / \mathrm{L} \mathrm{e}$ pirilamina com $10^{-5} \mathrm{~mol} / \mathrm{L}$, resultando em $\mathrm{pD}_{2}{ }_{2}$ de 5,66 e 5,36; respectivamente. Da comparação com difenidramina, concluiuse que a clemastina foi cerca de 10 vezes mais potente no efeito competitivo enquanto a pirilamina foi menos potente. Quanto ao componente não-competitivo, a clemastina foi mais eficaz que a difenidramina enquanto a pirilamina foi menos eficaz. Se os efeitos obtidos com a clemastina e pirilamina no íleo isolado também se observarem quando empregados na terapêutica, in vivo, é de se esperar que a clemastina apresente mais efeitos adversos (anticolinérgicos) do que a pirilamina.

Descritores: íleo de cobaio in vitro, histamina, anti-histamínicos, clemastina, difenidramina, pirilamina.

Apresentada: 25 fevereiro 2005

*Dissertação de Mestrado n. 398 (Especialidade: Anestesiologia, Farmacologia e Terapêutica Animal). 58f. Programa de Pós-graduação em Ciências Veterinárias [www.ufrgs.br/ppgcv], Faculdade de Veterinária - UFRGS, Porto Alegre/RS. CORRESPONDÊNCIA: L.C. Vieira [lutinavieira@yahoo.com.br] \& A. Langeloh [00000614@ufrgs.br]. 


\title{
Comparing antihistaminic activity of clemastine and pyrilamine in guinea pig ileum ${ }^{* *}$
}

\author{
LUCIANE CRISTINA VIEIRA
}

\author{
Augusto Langeloh (Adviser - UFRGS)
}

Committee: Eliane Maria Zanchet (UFSM), Fátima Tereza Alves Beira (UFPel), João Roberto Braga de Mello (UFRGS)

This study has compared antihistaminic drugs used on allergical pathologies of small animals. The isolated guinea pig ileum was used to evaluate the pharmacological variables $\mathrm{ED}_{50}, \mathrm{E}_{\text {máx }}, \mathrm{pD}_{2}, \mathrm{pD}_{2}$ and $\mathrm{pA}_{2}$. Concentration-responses curves for histamine and acetylcholine were obtained in absence(control) and presence of increasing concentrations of clemastine and pyrilamine. Diphenhydramine was used as reference drug. The results showed that pyrilamine and clemastine acted effectivelly as antihistaminic in guinea pig isolated ileum. The main effect was competitive, but, in higher concentration revealed also a nocompetitive effect. Clemastine ( $\left.\mathrm{pA}_{2}=8,63\right)$ was 10 times more powerfull that the pyrilamine $\left(\mathrm{pA}_{2}=7,61\right)$ as antihistaminic, but in addition presented a significant $\left(\mathrm{P}<0,05\right.$; ANOVA, Bonferroni) anticolinergic effect $\left(\mathrm{pA}_{2}=7,48\right)$, wich wasn't observed with pyrilamine. Both clemastine and pyrilamine presented an anticolinergic effect throught a no-competitive mechanism in more elevated concentrations: clemastine from $10^{-7} \mathrm{~mol} / \mathrm{L}$ and pyrilamine from $10^{-5} \mathrm{~mol} / \mathrm{L}$, resulting in $\mathrm{pD}{ }_{2}$ of 5,66 and 5,36 respectivelly. Through the comparison with diphenhydramine, it could be concluded that clemastine is about 10 times more potent against histamine in the competitive effect while pyrilamine has almost the same power. In relation to the no- competitive component, clemastine was more efficient then the diphenhydramine while the pyrilamine has smaller efficacy. If the effects observed with clemastine in the isolated ileum will also be observed when it is used in terapeutic (in vivo) it is expected to show more (anticolinergic) adverse effects than the pyrilamine.

Key words: guinea pig ileum in vitro, histamine, antihistaminics, clemastine, diphenhydramine, pyrilamine. 